\title{
Chemical aspects of the composition of industrial hemp seed products
}

\author{
Mykola Oseyko ${ }^{1}$, Nataliia Sova ${ }^{2}$, \\ Maryna Lutsenko ${ }^{3}$, Viktoriia Kalyna²
}

1 - National University of Food Technology, Kyiv, Ukraine

2 - Dnipro State Agrarian and Economic University, Dnipro, Ukraine

3 - Limited Liability Company «Desnaland», Hlukhiv, Ukraine

Keywords:

Hemp

Seed

Kernel

Oil

Functional

Amino acid

Article history:

Received 15.12.2018

Received in revised

form 16.04.2019

Accepted 30.09.2019

Corresponding

author:

Nataliia Sova

E-mail:

sova.natalia.89@

gmail.com

DOI: $10.24263 / 2304-$

974X-2019-8-3-11

\section{Abstract}

Introduction. The purpose of the paper is to study theoretical and experimental aspects of the chemical composition and quality of hemp seed products, including oxidation processes in oils, seeds and processing products.

Materials and methods. Research materials are industrial hemp seeds of «Hlesiia» variety, pressed oil and oil compositions, hemp seeds kernel. The quality of the investigated materials was evaluated according to standard and industry methods and to Codex Alimentarius.

Results and discussion. The obtained hemp oils by the content of fatty acids, phospholipids, vitamins $\mathrm{A}$ and $\mathrm{E}$ have high biological value, and by the content of tocopherols significantly outweigh sunflower, sesame and amaranth oils. The sample of MM60 pressed oil is preferred for antioxidant resistance. The ratio of essential fatty acids is close to ideal: Omega-6 and Omega-3 as 3.0:1 - 3.7:1, while in linseed oil $1: 3.6$. Hemp oil also contains biologically valuable gammalinolenic acid. Spectrophotometric method confirmed the presence of carotenoids and chlorophylls in pressed hemp oil. Vitamin A content in oil is $78 \mathrm{mg} / \mathrm{kg}$, vitamin E (total) - 562.8 $\mathrm{mg} / \mathrm{kg}$. Hemp oil is better stored at $8 \pm 2{ }^{\circ} \mathrm{C}$ without light access by chemical indicators. The obtained hemp oil and oil compositions are of good quality. The composition with a peroxide and acid value of less than 1 and a higher oil output is preferred. The quality of hemp seeds (without the shell) improves compared to the output seeds. The content of oil and protein increased 1.5 times, macro and microelements: phosphorus 1.5 times, ferro 1.25 times, zinc and cobalt 2 times. Hemp seeds without the shell have a high content of essential amino acids and a high content of lysine, which is usually deficient.

Conclusions. It is recommended the hemp oil and hemp seeds kernel in the production of functional food. 


\section{- Food Technology -}

\section{Introduction}

The qualitative and quantitative composition of lipids and related compounds of oilprotein or protein-oil raw materials varies on a long way from the field, during transportation and storage of seeds and its complex processing, taking into account various chemical and technological influences. The chemical composition of lipids of pressed oils and oilcake determines their quality, ecological and economic efficiency, functional-technological and special properties and biological value for consumers [1-4].

The range of the use of hemp products in global economy is steadily expanding, and industrial technologies for the ingredients production are being developed for use in innovative industries. Cannabis acquires the status of strategic culture, the cultivation, and processing of which is a priority for economic policies of governments in many developed countries and private business [5]. Cannabis sativa seed oil has both medicinal and industrial uses [6].

In the oil and industrial hemp seeds, the ratio of unsaturated fatty acids Omega-3 and Omega-6 is balanced for human health and in line with the recommendations of the World Health Organization (WHO). The world's hemp seed producers position it as a unique source of protein [7]. Further improvements of oilseeds complex processing technology, including the identification of chemical aspects of the composition and hemp seeds quality, oils, composite oils, and products on their base, will ensure the production of competitive functional products in the systemic health concept [8-11].

The purpose of the research is to study the theoretical and experimental aspects of the chemical composition and quality of hemp seed products.

\section{Literature analysis}

Chemical and biochemical aspects of the oxidation and scorching of acylglycerols in oilseeds and in vegetable oils. Acylglycerols in vegetable oils are unstable during storage. They are the most labile components of fat and raw materials (seeds, intermediates) and finished products. The instability of oils and fats is a consequence of the peculiarities of their chemical structure. The conversion of triacylglycerols can be divided into reactions occurring with the participation of ester groups and reactions occurring with the participation of hydrocarbon radicals. Oxidation of lipids and oils is based on their interaction with the oxygen of air; the rate of their oxidation is individual and depends on many factors. The substrates of this reaction are generally unsaturated fatty acids. The lipids of tissues of oil raw materials, especially at the beginning of storage are subject to biochemical changes [1, $2,12,13]$.

Triacylglycerols of unsaturated fatty acids are oxidized more quickly than saturated fatty acids. Free fatty acids are oxidized faster than in the composition of triacylglycerols. Fatty acid oxidation is a complex multi-stage process. The ability to oxidize increases with unsaturation and decreases as carbon atoms in fatty acid molecules increase.

Saturated fatty acids are oxidized only at temperatures above $60{ }^{\circ} \mathrm{C}$, while polyunsaturated fatty acids are oxidized even in the frozen state. Similar oxidation reactions are possible in other unsaturated substrates: phospholipids, hydrocarbons, squalene, vitamin A and carotenoids, vitamin E. It should be emphasized that vitamin E as a natural antioxidant delays lipid oxidation and the formation of volatile compounds.

Oxygen absorption is divided into three periods: induction, monomolecular (at the end of this period, a taste of rancidity appears), finally, bimolecular when the intensity of oxygen absorption increases sharply. The spontaneous self-oxidation of lipids (oils) always occurs, 
even when stored in a cooled state, protected from light, in non-metallic containers. This is because there are always molecules with energy higher than the average in the system. The rate of oxidation depends on the content of the antioxidant system. Very often, a decrease in the rate of initiation reactions is a limiting factor in lipid oxidation. [1].

According to [14], the oxidative stability of flax and hemp oils, as well as their compositions devoid of minor components, was evaluated in the dark at $60{ }^{\circ} \mathrm{C}$ and under fluorescent light at $27{ }^{\circ} \mathrm{C}$. Several analytical methods have been used to evaluate the oxidative stability of oils. Oil extracts for the absorption of 1,1-diphenyl-2-picrylhydrazyl (DPPH) and their total phenolic content were also investigated. The results showed that the bioactive components of these edible oils play an important role in their oxidative stability. However, the composition of phenolic antioxidants and the total content of tocopherols in oil, as well as the type of pigments present, contribute to their stability. Flaxseed oil and hemp oil compositions that were not treated were more stable. In addition, hemp oil had higher oxidative stability than untreated linseed, as evidenced by the purification of the DPPH radical and the total phenol content.

In paper [15], 10 different polar solvent systems were investigated for 40 samples of kernels and cases of two varieties of hemp (Bama and Yunma No. 1). The capacity of the extracts for radical extraction was evaluated using 2,2-diphenyl-1-picrylhydrazyl (DPPH) and 2,2'-azino-bis (3-ethylbenzothiazoline-6-sulfonic acid) (ABTS) assays. The total content of phenols was determined using the phenolic reagent Folin-Sioccalteu. Correlation analysis showed that the antioxidants in hemp belong to the phenolic DPPH analysis and are suitable for evaluating the activity of radical extraction. Two compounds having predominant antiradical activity were isolated from hemp extract using macroporous resin, LH-20 gel permeation chromatography, and high performance liquid chromatography. The compounds were identified as N-trans-caffeyltyramine and cannabisin B (resolution of mass spectra, nuclear magnetic resonance spectra, and ultraviolet data). The two compounds exhibited significant high DPPH purification activity and a protective effect against in vitro oxidation of low-density human lipoprotein compared to flaxseed, grape and soy extracts. This suggests that hemp extract is a potential source of natural antioxidants.

In work [16], the organoleptic characteristics of hemp oil samples were investigated, and the comparative analysis of the physicochemical parameters and the fatty acid composition of the oil from organic and conversion hemp seeds were performed.

The quality of 14 oils sold in Europe was evaluated by the author's team research [17] (2018). Deep chemical profiling of cannabinoids, terpenes, and oxidation products was performed using gas chromatography with mass spectrometry and high performance liquid chromatography-Q-Exactive-Orbitrap-MS to improve knowledge about the characteristics of cannabinoids oils. Nine of the 14 samples tested had concentrations that differed markedly from the claimed amount, and the remaining five had optimal cannabinoids. The results indicate the broad variability of the cannabinoid profile, which justifies the need for strict and standardized rules. In addition, the terpenes can serve as an indicator of the quality of hemp varieties, while the profile of lipid oxidation products can help to evaluate the stability of the oil used as a medium for cannabinoid-rich extracts. This is fundamental to consumer safety since cannabinoid preparations in oil are also used for therapeutic purposes, regardless of whether they are registered as food supplements.

Thus, the problem of lipid oxidation (including peroxides) is associated with the formation of volatile compounds that can limit the storage time of raw materials, affect the process, storage period, quality and safety of oil-containing products. 
Chemical and technological aspects of preparation and processing of industrial hemp seeds. New Ukrainian varieties of hemp Viktoriia, Hliana and Nika do not contain tetrahydrocannabinol and have been listed in the State Register since 2011 [18]. This contributes to the development of production and processing of industrial hemp seeds.

According to paper [19], the quality of processing of domestic industrial hemp seeds must be ensured at the stages of harvesting, cleaning, drying, and storage.

In Canada, an approved seed composition of ten industrial hemp varieties is used [20].

Canada is the largest producer of hemp seeds and has been exporting its consignments to EU and US countries for a long time. The area of hemp seed production in Canada is much larger than in France and ten times larger than in Chile, the Netherlands or South Korea. Hemp is also grown in Italy, Serbia, Montenegro, Poland, Hungary, Belarus, India, Iran, Turkey, and other countries [21].

Since 2019, twelve varieties of hemp have been listed in the «State Register of Plant Varieties Suitable for Distribution in Ukraine» [22].

Hemp seeds grown in Ukraine contain on average, $30-35 \%$ of lipids, $17-25 \%$ of proteins, $14-27 \%$ of fiber, 2.5-7\% of crude ash, non-nitrogenous extractives $14-27 \%$ [23].

The main products of industrial hemp seed processing in Ukraine are oil, flour, bran, and protein. Also halva, salt, and manna are made from hemp seeds. In the world, hemp and their components are used for the manufacture of products, preparations and consumer goods [24]. The health effect of the use of cannabis seeds in food is a scientifically sound fact [25].

Hemp oil contains a unique amount of unsaturated fatty acids compared to known vegetable oils. In the oil of hemp seeds the ratio of essential fatty acids is close to the ideal of the WHO recommendations: Omega-3 and Omega-6 as 1:3, while in linseed oil - 4:1, in rapeseed $-1: 2$, in soybean $-1: 7$ [26].

The fatty acid composition and oxidizing ability of oils from different varieties of hemp seeds depend on different localization and region [27].

Therapeutic, preventive, cosmetic effects of using hemp oil are scientifically proven facts. The inclusion of hemp oil in the daily diet can eliminate the broad spectrum of diseases or prevent their development [28].

Oil and seeds, in addition to their nutritional value, have shown a positive effect on the normalization of cholesterol, triacylglycerols, blood pressure, treatment of dermatitis. In addition, hemp oil can be used as an integrator for the preparation of traditional medicines [29].

New Zealand oils obtained by cold-pressed hemp, flax, and rapeseed material were analyzed for the compositions of fatty acids, tocopherols, $\beta$-carotene, chlorophyll, total phenols, flavonoids, color, quality, melting and crystallization characteristics. The dominant fatty acid of canola, hemp and linseed oil was oleic $(57.0 \pm 0.0 \%)$, linoleic $(55.7 \pm 0.3 \%)$ and linolenic acid $(58.7 \pm 1.2 \%)$, respectively $(\mathrm{p}<0.05)$. Hemp seed oil had the highest content of tocopherol, flavonoid, and phenolic acid. A significant difference in the color of the oils $(\mathrm{p}<0.05)$ was found due to the chlorophyll content of the oil. All oils had low moisture content and volatile matter, non-volatile substances and free fatty acids. The values of peroxide, p-anisidine, conjugated dienoic acid, iodine, and specific extraction of cold-pressed oil at 232 and $270 \mathrm{~nm}$ were within the limits allowed by the general rules [30].

To increase the shelf life and maintain the optimum balance of the most essential unsaturated fatty acids, 2:1:3 and 3:1:4 flax, mustard and hemp oils are recommended [31].

In paper [32], secondary metabolites of hemp seeds were studied to identify bioactive compounds that could contribute to their health benefits. Four new lignanamides have been isolated. Their structures were first identified on the basis of nuclear magnetic resonance, gas chromatography with mass spectrometry, ultraviolet and infrared radiation, as well as in 
comparison with the literature. Lignanamides 2, 7 and $9-14$ showed good antioxidant activity, among which 7,10 and 13 also inhibited acetylcholine esterase in vitro. Newly identified compounds are added to the diversity of the composition of hemp seeds, and bioassays suggest that hemp seeds, with lignanamides as nutrients, can be a good source of bioactive and protective compounds.

In recent years, the use of by-products in the production of hemp oil, such as antioxidants, proteins, essential amino acids, and dietary fiber has been increasingly emphasized in the food industry [33-35].

In the process of industrial hemp seeds processing when extracting oil (lipids) simultaneously the oilcake is received. Depending on extraction method, the oilcake contains protein, oil, polyunsaturated fatty acids, phospholipids, carotene, phytosterols, micro and macronutrients, cellulose, etc. [10,16], which are important and contribute to the prevention and recovery of the organism, in particular in the systemic health concept (KTIOL ${ }^{\circledR}$ system) [11].

Based on the analytical review of scientific and technical information, it is found that the discovery of new theoretical, scientific, innovative and practical knowledge regarding the complex processing of industrial hemp seeds, including Ukrainian breeding, into functional foods, supplements, and preparations in the systemic health concept is fundamental, environmental, economic, social and gerontological problem.

\section{Materials and methods}

\section{Materials}

The object of study is the chemical aspects of the technology of industrial hemp seeds complex processing.

Research materials are industrial hemp seeds of Ukrainian breeding, in particular, the «Hlesiia» variety, press oil and oil compositions, collapsed hemp seeds. The distinctive feature of this variety is the lack of tetrahydrocannabinol.

Samples of hemp oil and oil compositions were obtained using the press method: P250 oil on a screw press of PS 250 [16]; MM60 oil on MMS-60 auger press [16]; KTIOL-LK oil and oil compositions on the LPS 5 auger press [1]. Quality indicators, in particular chemical, physical and organoleptic of the investigated materials were evaluated according to standard and industry methods and to Codex Alimentarius $[1,16]$.

\section{Determination of the fatty acid composition of press oil}

Preparation of prototypes. Samples were prepared as follows [1]: a sample of oil (2 drops) was dissolved in $2 \mathrm{ml}$ of hexane in a test tube. $100 \mu \mathrm{l}$ of sodium methylate solution in methanol at a concentration of $2 \mathrm{~mol} / \mathrm{dm}^{3}$ was added by pipette and stirred for $2 \mathrm{~min}$. Then 1 $\mathrm{ml}$ of dimethyl carbonate was added, shaken for $2 \mathrm{~min}$, the mixture was brought to the mark with distilled water. The top layer containing fatty acid methyl esters was further separated. The top layer was collected by micropipette and filtered through anhydrous sodium sulfate.

The procedure for conducting research. The volume of the injected samples is 1-2 $\mu 1$. «Supelco» fatty acid of methyl esters was used as external standards. The identification of fatty acids was performed by comparing their retention time with known samples. 
Description of methods and installations. The fatty acid composition of hemp oil was determined by gas chromatography [1]. Detection of fatty acid methyl esters was performed on an Agilent 7890 gas chromatograph (USA). The length of the chromatographic column is $50 \mathrm{~mm}$; the inner diameter is $0.22 \mathrm{~mm}$. The temperatures of the evaporator, the detector, and the thermostat were respectively 250,250 and $150{ }^{\circ} \mathrm{C}$.

Processing of research results. The fatty acid content was calculated as a percentage of their total. Chromatogram registration and processing were performed using HP ChemStation software.

\section{Determination of the presence of hemp oil pigments}

Preparation of prototypes. Hemp oil solution in hexane concentration of $10 \mathrm{mg} / \mathrm{ml}$ was prepared in the ultraviolet domain, and in the visible domain of $40 \mathrm{mg} / \mathrm{ml}$ to determine the absorption spectra of hemp oil solutions [1].

The procedure for conducting research. To determine the absorption spectra of hemp oil solutions in the ultraviolet domain, studies were performed in quartz cuvettes $2 \mathrm{~mm}$ thick and $10 \mathrm{~mm}$ in the visible domain [1].

Description of methods and installations. The presence of hemp oil pigments was determined on a SPECORD M40 spectrometer (Germany), which is a controlled microcomputer, a two-beam instrument for measuring transmission and absorption in the ultraviolet and visible domains of the spectrum. The instrument allows determining the transmittance, extinction or sample concentration as a function of wave number or wavelength.

The SPECORD M40 spectrophotometer contains two radiation sources: the DZE/I deuterium lamp for the ultraviolet domain $(185-360 \mathrm{~nm})$ and the halogen lamp 6V, 20W for the visible spectrum $(320-900 \mathrm{~nm})$. Control of all functions of the device is carried out through a micro-computer.

Processing of research results. The SPECORD M40 is coupled to a managed recorder computing device for spectrum imaging.

\section{Determination of the amino acid composition of the original and collapsed industrial hemp seeds}

Preparation of prototypes. Fine-grained cation exchanger (resin) is used for the separation of amino acids, which is a copolymer of styrene and divinylbenzene of spherical form with the functional group $-\mathrm{SO}_{3}{ }^{-}$. The hydrolysis method with hydrochloric acid was used to prepare the samples.

Procedure for conducting research. To ensure separation of amino acids mixture on the column, the cation exchanger was pre-equilibrated with a lithium citrate buffer solution. When applied to a column of amino acids mixture at pH 2.2 molecules of amino acids were attracted by ionic forces to the sulfo group of the resin with its positively charged amino group and squeezed ions $-\mathrm{Li}+$, distributed along the column depending on the size of the positive charge. The basic amino acids lysine, arginine, and histidine have the highest positive charge, so they immediately and firmly bind to the resin. Acid amino acids glutamic and asparagine have the least positive charge, so they passed through the entire column and connected with the resin last. Next, the elution (extraction) of amino acids took place under certain conditions: at high speed, at high pressure and temperature, and using five stages of eluent change. The sequence of the release of individual amino acids from the chromatographic column was determined not only by the properties of the cation exchanger 
but by the composition and temperature of the eluent. For the registration of amino acids in eluent, the detection method of ninghydrin was used.

Description of methods and installations. The quantitative amino acid composition of the original and collapsed industrial hemp seeds was determined by ion-exchange liquidcolumn chromatography on an automatic T 339 amino acid analyzer (Czech Republic).

Processing of research results. To calculate the number of amino acids in the test sample, a standard mixture of amino acids with a known concentration of each amino acid was applied to the amino acid analyzer column previously. The peak area of each amino acid was calculated on the chromatogram. The number of micromoles of each amino acid $\left(\mathrm{X}_{1}\right)$ in the solution under study was calculated by the formula:

$$
\mathrm{X}_{1}=\frac{\mathrm{S}_{1}}{\mathrm{~S}_{0}}
$$

where $S_{1}$ is the peak area (or height) of the amino acid in the sample;

$\mathrm{S}_{0}$ is the peak area (or height) of the same amino acid in a solution of amino acids standard mixture, corresponding to 1 micromole of the number of each amino acid.

\section{Results and discussion}

\section{Quality indicators of hemp pressed oil}

In order to preserve the biological value of hemp oil in technology, the method of seed pressing is used $[1,16]$. The technology of hemp oil differs from other oil crops in that they do not use pre-wet-heat treatment of the material. This is due to the type of press, the technological parameters (conditions) of the press, the output and the antioxidant resistance of hemp oil. Seeds of industrial hemp by moisture content and purity must comply with the regulations in force as for seeds to be stored [19].

Quality indicators of pressed filtered hemp oil are presented in Table 1.

Characteristics of quality indicators of pressed hemp oil samples

Table 1

\begin{tabular}{|c|c|c|c|}
\hline № & Indicators & $\begin{array}{c}\text { Sample of } \\
\text { oil P } 250\end{array}$ & $\begin{array}{l}\text { Sample of oil } \\
\text { MM60 }\end{array}$ \\
\hline 1 & Peroxide number, $1 / 2 \mathrm{O} \mathrm{mmol} / \mathrm{kg}$ & $14.3 \pm 0.5$ & $8.6 \pm 0.3$ \\
\hline 2 & Acid number, $\mathrm{mg} \mathrm{KOH} / \mathrm{g}$ & $2.6 \pm 0.09$ & $1.6 \pm 0.08$ \\
\hline 3 & Moisture and volatile matter content, $\%$ & $0.1 \pm 0.003$ & $0.2 \pm 0.005$ \\
\hline 4 & Content of low-fat impurities, $\%$ & $0.1 \pm 0.003$ & $0.1 \pm 0.003$ \\
\hline 5 & $\begin{array}{l}\text { The content of phospholipids, } \mathrm{mg} / \mathrm{kg} \text {, } \\
\text { in terms of stearooleolecitin, } \%\end{array}$ & $\begin{array}{c}88.5 \pm 2.6 \\
0.2\end{array}$ & $\begin{array}{c}69.3 \pm 2.1 \\
0.2\end{array}$ \\
\hline 6 & Total ash content, $\%$ & $0.1 \pm 0.05$ & $0.1 \pm 0.05$ \\
\hline 7 & Iodine number, $\mathrm{g} \mathrm{J}_{2} / 100 \mathrm{~g}$ & $158.5 \pm 1.6$ & $152.0 \pm 1.5$ \\
\hline 8 & $\begin{array}{l}\text { Vitamin content, } \mathrm{mg} / \mathrm{kg} \text { : } \\
\mathrm{A} \\
\mathrm{E}, \\
\text { including: } \\
\alpha \text {-tocopherol } \\
\beta \text {-Tocopherol }+\gamma \text {-Tocopherol } \\
\delta \text {-tocopherol }\end{array}$ & $\begin{array}{c}78.0 \\
562.8 \\
\\
234.0 \\
316.0 \\
12.8 \\
\end{array}$ & $\begin{array}{c}82.0 \\
582.2 \\
\\
246.2 \\
322.0 \\
14.0 \\
\end{array}$ \\
\hline
\end{tabular}


From Table 1 data analysis it follows that the content of fatty acids, phospholipids, vitamins $\mathrm{A}$ and $\mathrm{E}$ (tocopherols), the degree of their unsaturation the obtained pressed oils have a high biological value. For antioxidant resistance, a sample of MM60 pressed oil is preferred. In further studies of organic seeds of industrial hemp new varieties, it is necessary to clarify the influence of technological equipment and technological conditions of conducting the pressing process on the composition and quality of hemp oil.

\section{Fatty acid analysis of pressed oil}

To confirm data on hemp oil biological value from the seeds of the Ukrainian breeding of «Hlesiia» variety in comparison with linseed oil, their fatty acid composition was analyzed. The research results of fatty acids content, the content of which is $\geq 0.5 \%$, are given in Table 2.

Fatty acid composition of hemp and flaxseed oil

Table 2

\begin{tabular}{|c|l|c|c|c|}
\hline \multirow{2}{*}{ № } & \multicolumn{1}{|c|}{ Fatty acid } & \multicolumn{3}{c|}{ Acid content, \% } \\
\cline { 3 - 5 } & & $\begin{array}{c}\text { Sample of } \\
\text { oil P 250 }\end{array}$ & $\begin{array}{c}\text { Sample of } \\
\text { oil MM60 }\end{array}$ & $\begin{array}{c}\text { Flaxseed } \\
\text { oil }\end{array}$ \\
\hline 1 & C 16: 0 palmitic & 5.7 & 6.3 & 5.6 \\
\hline 2 & C 18: 0 stearic & 3.0 & 3.2 & 5.4 \\
\hline 3 & C 18: 1 Oleic (Omega-9) & 13.6 & 13.3 & 17.9 \\
\hline 4 & C 18: 2 linoleum (Omega-6) & 54.8 & 56.9 & 15.5 \\
\hline 5 & C 18: 3 alpha-linolenic (Omega-3) & 18.5 & 16.0 & 55.3 \\
\hline 6 & C 18: 2 Gamma Linolenic (Omega-6) & 1.3 & 2.8 & 0.0 \\
\hline 7 & C 20: 0 peanuts & 2.4 & 0.8 & 0.2 \\
\hline
\end{tabular}

It is found that the ratio of essential fatty acids in hemp oil is close to perfect: Omega6 and Omega-3 as 3.0:1 - 3.7:1, while in linseed oil is 1:3.6. Hemp oil also contains biologically valuable gamma-linolenic acid, which is quite rare in vegetable raw materials. Nowadays, it is widely recognized [1,9] the exceptional importance of Omega-3 polyunsaturated fatty acids for maintaining physical and mental health and preventing a number of diseases.

\section{Presence of hemp oil pigments}

The absorption of monochromatic radiation by hexane solution of hemp oil in the ultraviolet domain of the spectrum is presented in Figure 1.

The spectrum analysis (Figure 1) revealed a band of 200-350 nm, namely, a wide band in the area of 200-250 nm with a maximum at $240 \mathrm{~nm}$ with an optical density of $\mathrm{D}=1.79$. This band is associated with the absorption of saturated and unsaturated fatty acids. The spectra of polyunsaturated fatty acids with isolated double bonds are no different from those of monounsaturated fatty acids since the determining chromophore in the spectra is isolated ethylene bonds. A symmetrical wide band from $260 \mathrm{~nm}$ to $310 \mathrm{~nm}$ with a maximum at 280 $\mathrm{nm}$ with an optical density of $\mathrm{D}=4.0$ characterizes the absorption of main triacylglycerols.

The absorption of monochromatic radiation by hexane solution of pressed hemp oil in the visible domain of the spectrum is presented in Figure 2. 


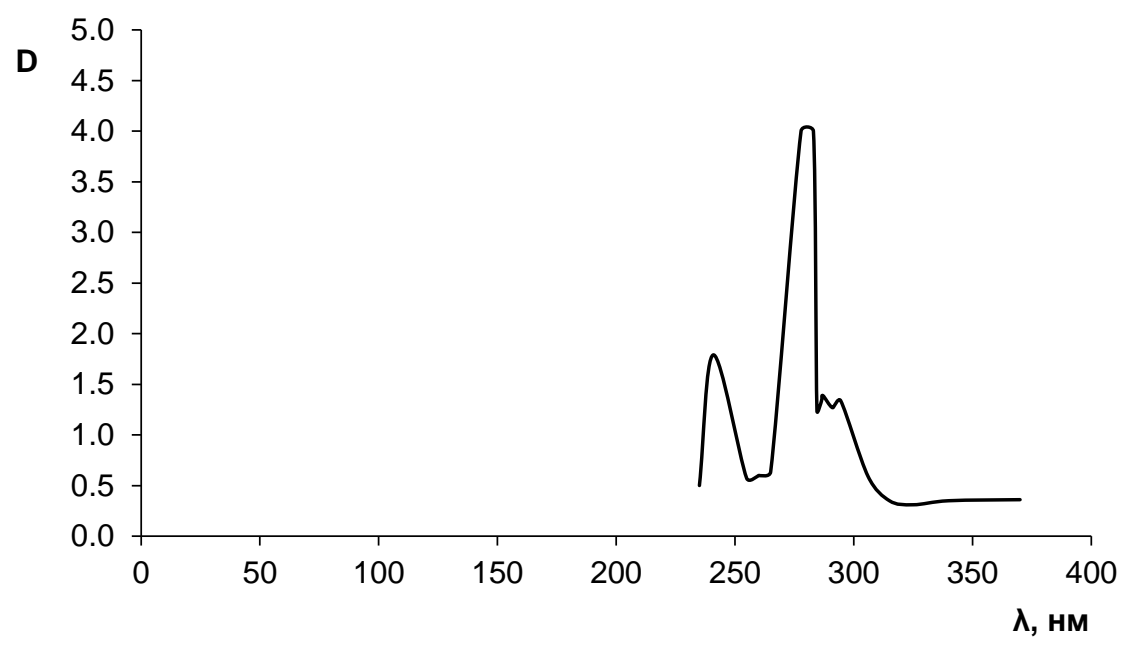

Figure 1. UV spectrum of a hexane solution of hemp oil: D - optical density, $\lambda$ - wavelength

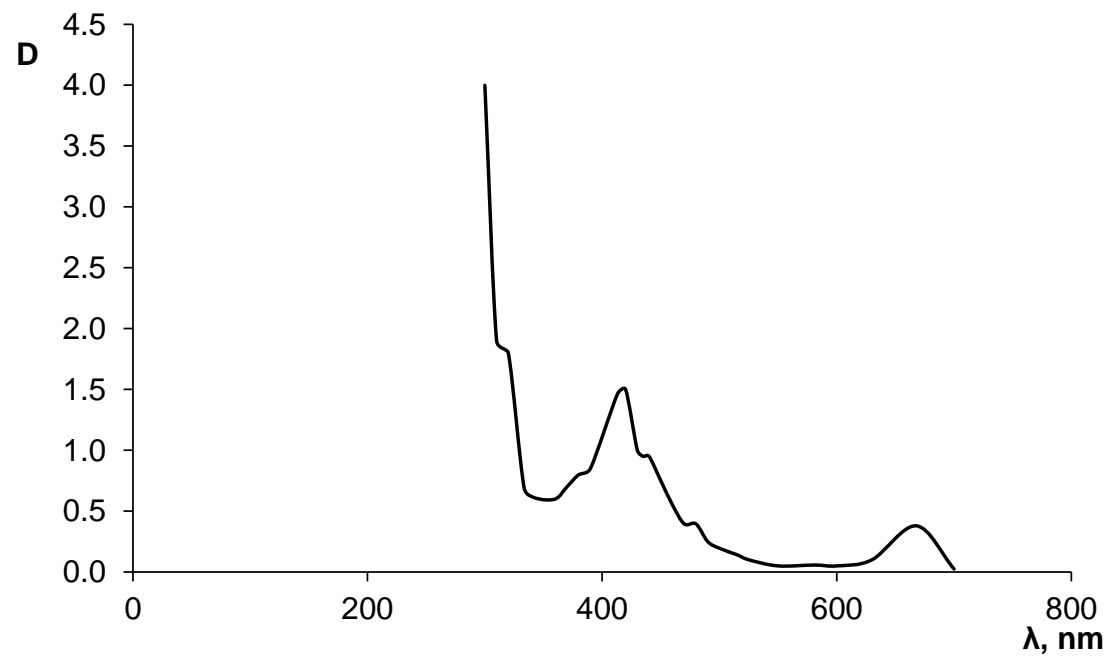

Figure 2. A spectrum of hexane solution of hemp oil in the visible domain: $D$ - optical density, $\lambda$ - wavelength

In spectrum analysis (Figure 2), a band of 360-750 nm was detected, namely, one broad band in 400-480 $\mathrm{nm}$ range with a maximum at $420 \mathrm{~nm}$ with an optical density $\mathrm{D}=1.50$ is associated with carotenoid absorption. The peak in the area of 500-750 nm at $670 \mathrm{~nm}$ with an optical density of $\mathrm{D}=0.37$ refers to chlorophyll a. That is, the hemp oil obtained from the seeds of Ukrainian breeding contains carotenoids and chlorophyll as a part of natural biologically active substances.

Spectrophotometry confirmed the presence of carotenoids and chlorophylls in pressed hemp oil. Vitamin A content in oil is $78 \mathrm{mg} / \mathrm{kg}$, vitamin $\mathrm{E}$ (total) is $562,8 \mathrm{mg} / \mathrm{kg}$. 


\section{Tocopherols content in vegetable oils}

Comparison of tocopherols content and their isomers in hemp press crude oil and in vegetable oils (according to Codex Alimentarius) is presented in Table 3.

Table 3

Tocopherol content of hemp pressed oil, sunflower, sesame and amaranth oils

\begin{tabular}{|c|c|c|c|c|c|}
\hline \multirow{2}{*}{ Oil } & \multirow{2}{*}{$\begin{array}{c}\text { Total } \\
\text { content, } \\
\text { mg\% }\end{array}$} & \multicolumn{3}{|c|}{ Isomers, $\%$ of the total content } & \multirow{2}{*}{$\begin{array}{c}\text { Content } \\
\text { interval, } \\
\text { mg\% }\end{array}$} \\
\hline & & $\mathbf{a}$ & $\boldsymbol{\beta}$ & $\gamma+\delta$ & \\
\hline $\begin{array}{l}\text { Sunflower high- } \\
\text { oleic refined }\end{array}$ & $96 \pm 0.85$ & $91.5 \pm 0.8$ & $8.5 \pm 0.05$ & - & $\begin{array}{l}40.3- \\
102.1 \\
\end{array}$ \\
\hline $\begin{array}{l}\text { Sesame is not } \\
\text { refined }\end{array}$ & $84 \pm 0.7$ & $51.4 \pm 0.55$ & $43.0 \pm 0.4$ & $5.6 \pm 0.05$ & $\begin{array}{l}50.4- \\
114.0 \\
\end{array}$ \\
\hline $\begin{array}{l}\text { Amaranth is } \\
\text { refined }\end{array}$ & $215 \pm 1.5$ & $49.1 \pm 0.35$ & $42.4 \pm 0.5$ & $8.5 \pm 0.1$ & $\begin{array}{l}31.4- \\
347.2 \\
\end{array}$ \\
\hline $\begin{array}{l}\text { Hemp press is } \\
\text { unrefined }\end{array}$ & 562.8 & 41.6 & 48.6 & 9.8 & - \\
\hline
\end{tabular}

Note $^{\mathrm{a}}$ - for Codex Alimentarius.

According to the content of tocopherols (Table 3), hemp pressed oil significantly outweighs sunflower, sesame and amaranth oil, which confirms its high biological value.

\section{Indicators of hemp oil quality during storage}

Samples obtained from industrial seeds of the 2018 yeld were investigated to determine the storage conditions of hemp oil. The oil was obtained from the PS-250 auger press (Institute of bark crops) and had initial data: acid number $-0.4 \mathrm{mg} \mathrm{KOH} / \mathrm{g}$, peroxide number $-6.01 \frac{1}{2} \mathrm{O} \mathrm{mmol} / \mathrm{kg}$. Samples of hemp oil in sachet packages were stored under the conditions: 1 and 2 at a temperature of $18-25^{\circ} \mathrm{C}, 1$ - with light access, 2 - without light access, 3 - in a refrigerator at $8 \pm 2{ }^{\circ} \mathrm{C}$.

The results of determining the chemical properties of the hemp oil samples after a fivemonth shelf life are presented in Table 4.

\section{Chemical characteristics of hemp oil samples}

Table 4

\begin{tabular}{|c|l|c|c|c|}
\hline № & Indicator & Sample 1 & Sample 2 & Sample 3 \\
\hline 1 & $\begin{array}{l}\text { Peroxide number, 1/2 O } \\
\text { mmol/kg }\end{array}$ & 50.2 & 22.6 & 8.9 \\
\hline 2 & Acid number, mg KOH/g & 3.6 & 3.6 & 3.4 \\
\hline 3 & Anisidine number, mind. units & 3.7 & 3.0 & 1.3 \\
\hline 4 & Totox indicator & 105.1 & 48.2 & 19.1 \\
\hline
\end{tabular}

From the data table, 4 follows that hemp oil is better stored at $8 \pm 2{ }^{\circ} \mathrm{C}$ without light access by chemical terms and at a lower integral value (totox). 


\section{Quality indicators of oil compositions}

One way to increase the resistance of oils to oxidation and sagging is to scientifically prove the creation of oil or oil-fat compositions [1].

In order to improve the antioxidant resistance and functional and technological properties of hemp oil in the systemic concept of health $[8,11]$ and to expand the range of oil-fat compositions, products and preparations, chemical quality indicators, output of oil and oilcake during the first pressing of the hemp seed and mixtures of flax seeds and hemp KTIOL-LK were investigated. Source moisture of seeds: hemp $-9.3 \pm 0.2 \%$, flax $-5.5 \pm 0.1$ $\%$; press - screw PLC-5, matrix diameter $10 \mathrm{~mm}$, pressing temperature $-105 \pm 2{ }^{\circ} \mathrm{C}$. KTIOLLK oil compositions are obtained by pressing mixtures of flax and hemp seeds in the ratio: KTIOL-LK11 - 1:1; KTIOL-LK31 - 3:1; KTIOL-LK91 - 9:1. The results of the study are presented in Table 5.

Table 5

Chemical quality indicators and oil output when pressing hemp seeds and the mixture of flax and KTIOL-LK hemp seeds

\begin{tabular}{|c|l|c|c|c|c|c|}
\hline $\begin{array}{c}\text { Sample } \\
\text { No. }\end{array}$ & $\begin{array}{c}\text { Oil/oil } \\
\text { composition }\end{array}$ & $\begin{array}{c}\text { Output of } \\
\text { pressed oil, } \\
\mathbf{\%}\end{array}$ & $\begin{array}{c}\text { Output of } \\
\text { oilcake, \% }\end{array}$ & $\begin{array}{c}\text { Acid number } \\
\text { of the oil, mg } \\
\text { KOH/g }\end{array}$ & $\begin{array}{c}\text { Peroxide oil } \\
\text { number, mmol } \\
\mathbf{1} \mathbf{2} \mathbf{~ O / k g}\end{array}$ & $\begin{array}{c}\text { Oilcake } \\
\text { moisture } \\
\text { content, \% }\end{array}$ \\
\hline 1 & $\begin{array}{l}\text { Hemp oil of } \\
\text { first pressing }\end{array}$ & 23.8 & 75.3 & 1.4 & 1.4 & 9.8 \\
\hline 2 & $\begin{array}{l}\text { KTIOL- } \\
\text { LK11 oil }\end{array}$ & 26.1 & 73.3 & 0.8 & 0.7 & 8.1 \\
\hline 3 & $\begin{array}{l}\text { KTIOL-LK } \\
\text { 31 oil }\end{array}$ & 20.9 & 77.1 & 0.9 & 1.1 & 6.9 \\
\hline 4 & $\begin{array}{l}\text { KTIOL-LK } \\
\text { 91 oil }\end{array}$ & 20.9 & 78.0 & 0.9 & 1.1 & 6.3 \\
\hline
\end{tabular}

It was found (Table 5) that the chemical parameters, in particular, peroxide and acid numbers of pressed hemp oil and KTIOL-LK oil compositions (from hemp seeds and mixtures of flax seeds and hemp seeds) are of good quality. The KTIOL-LK11 oil composition (peroxide and acid numbers less than 1) with a higher oil output was preferred. The data obtained are consistent with theoretical, experimental and innovative data on modern vegetable oil technologies [1].

\section{Indicators of the quality of hemp seeds kernel}

One of the actual health problems of the population is providing different age groups with quality, safe lipid, and protein-lipid products $[1,8,11]$, in particular on the basis of ecological and economic complex processing of industrial hemp seeds of Ukrainian breeding.

Physicochemical indicators of the hemp seed quality that has been knocked out are presented in Table 6. 
Physicochemical indicators of the quality of the collapsed hemp seeds

\begin{tabular}{|c|c|c|c|c|}
\hline \multirow{3}{*}{ № } & \multirow{3}{*}{ Indicator } & \multicolumn{3}{|c|}{ Indicator value } \\
\hline & & \multicolumn{2}{|c|}{$\begin{array}{c}\begin{array}{c}\text { According to a study of hemp } \\
\text { seeds }\end{array} \\
\end{array}$} & \multirow{2}{*}{$\begin{array}{c}\text { According to } \\
\ll \text { Hemp- } \\
\text { Flax»b }\end{array}$} \\
\hline & & Collapsed & Output & \\
\hline 1 & Moisture content, $\%$ & $7.0 \pm 0.02$ & $8.4 \pm 0.02$ & $\leq 7.0$ \\
\hline 2 & Mass fraction of trash, $\%$ & $0.4 \pm 0.02$ & $3.3 \pm 0.15$ & - \\
\hline 3 & Acid number, mg KOH/g & $3.1 \pm 0.1$ & $3.3 \pm 0.1$ & - \\
\hline 4 & Mass fraction of oil a,$\%$ & $54.0 \pm 1$ & $33.3 \pm 0.5$ & 48.0 \\
\hline 5 & Mass fraction of protein ${ }^{a}, \%$ & $32.8 \pm 0.2$ & $22.5 \pm 0.15$ & 34.0 \\
\hline 6 & Mass fraction of fiber ${ }^{a}, \%$ & $5.5 \pm 0.03$ & $32.3 \pm 0.2$ & 6.0 \\
\hline 7 & Mass fraction of ash ${ }^{\mathrm{a}}, \%$ & $6.5 \pm 0.03$ & $5.91 \pm 0.03$ & - \\
\hline 8 & $\begin{array}{l}\text { Mass fraction of minerals }{ }^{\text {a }} \text { : } \\
\text { Phosphorus, g/kg } \\
\text { Calcium } \mathrm{g} / \mathrm{kg} \\
\text { Magnesium, g/kg } \\
\text { Ferum, } \mathrm{mg} / \mathrm{kg} \\
\text { Zinc, } \mathrm{mg} / \mathrm{kg} \\
\text { Cobalt, } \mathrm{mg} / \mathrm{kg} \\
\text { Manganese, } \mathrm{mg} / \mathrm{kg} \\
\text { Kuprum, } \mathrm{mg} / \mathrm{kg}\end{array}$ & $\begin{array}{c}13.5 \\
0.5 \\
2.7 \\
94.1 \\
111.8 \\
1.0 \\
38.3 \\
12.6\end{array}$ & $\begin{array}{c}8.9 \\
0.9 \\
2.4 \\
74.7 \\
56.1 \\
0.5 \\
59.4 \\
\text { not determined }\end{array}$ & $\begin{array}{c}13.8 \\
0.4 \\
5.6 \\
76.0 \\
85.0 \\
- \\
57.0 \\
9.0\end{array}$ \\
\hline
\end{tabular}

Note: ${ }^{\mathrm{a}}-$ in terms of solids.

$\mathrm{b}$ - hemp and flax processing company in the Netherlands and Romania.

From the data Table 6, it can be seen that the quality of collapsed hemp seed indicators is improved compared to the output seed. The oil and protein content increased 1.5 times, the macro- and trace elements (except calcium and manganese) increased: phosphorus -1.5 times, ferum -1.25 times, zinc and cobalt -2 times.

The ingredients of collapsed hemp seeds are biologically valuable and contribute to the prevention and healing of the organism, in particular in the systemic health concept (the KTIOL ${ }^{\circledR}$ system) $[8,11]$.

Since the production of hemp seed does not use the process of wet-heat treatment, it was important to determine the resistance of the product to the effects of microorganisms. Bacteria of Escherichia coli group, molds, yeasts and pathogens of the genus Salmonella were not detected in the test samples of the collapsed hemp seeds. It is important to observe the storage conditions of the hemp seed that has fallen off to prevent the development of pathogenic microflora, which may develop in the protein components of the unprotected core, with increasing humidity and temperature $[1,11]$. Due to the protein, oil and mineral content, the biological value of the product is increased for consumers.

Organoleptic characteristics of the collapsed hemp seed quality are followed: the color is light beige with shades of green; odor is inherent in healthy hemp seeds, odorless; taste is characteristic of hemp seeds, without bitterness, acid, and other foreign flavors.

The study of the composition of irreplaceable «i» and replaceable «r» amino acids in the collapsed hemp seeds is presented in Table 7. 
Amino acid composition of collapsed hemp seeds

\begin{tabular}{|c|c|c|c|c|c|c|c|c|}
\hline \multirow[t]{3}{*}{ № } & \multirow{3}{*}{ Indicator } & \multirow{3}{*}{$\begin{array}{c}\text { «i } ~ \\
\text { or } \\
\text { «r» }\end{array}$} & \multicolumn{6}{|c|}{ Value } \\
\hline & & & \multicolumn{2}{|c|}{$\begin{array}{c}\text { Collapsed } \\
\text { hemp seeds }\end{array}$} & \multicolumn{2}{|c|}{$\begin{array}{c}\text { Hemp seed } \\
\text { output }\end{array}$} & \multicolumn{2}{|c|}{$\begin{array}{l}\text { According to } \\
\text { «HempFlax» }\end{array}$} \\
\hline & & & $\mathrm{mg} / 100 \mathrm{~g}$ & $\%$ & $\mathrm{mg} / 100 \mathrm{~g}$ & $\%$ & $\mathrm{mg} / 100 \mathrm{~g}$ & $\%$ \\
\hline 1 & Alanine & «i $»$ & 1624 & 5.4 & 642 & 5.5 & 1760 & 5.6 \\
\hline 2 & Arginine & «i» & 4149 & 13.7 & 1409 & 12.1 & 3420 & 11.0 \\
\hline 3 & Aspartic acid & «i & 2616 & 8.6 & 1100 & 9.4 & 1870 & 5.9 \\
\hline 4 & Valine & $\langle\mathrm{r} »$ & 946 & 3.1 & 351 & 3.0 & 1880 & 6.0 \\
\hline 5 & Histidine & «i $\gg$ & 936 & 3.1 & 326 & 2.8 & 860 & 2.8 \\
\hline 6 & Glycine & «i $»$ & 1546 & 5.1 & 644 & 5.5 & 1420 & 4.6 \\
\hline 7 & Glutamic acid & «i» & 5546 & 18.4 & 2370 & 20.4 & 6340 & 20.3 \\
\hline 8 & Isoleucine & $\langle\mathrm{r} »$ & 833 & 2.8 & 323 & 2.8 & 1320 & 4.2 \\
\hline 9 & Leucine & «r» & 2023 & 6.7 & 791 & 6.8 & 2000 & 6.4 \\
\hline 10 & Lysine & $\langle\mathrm{r} »$ & 1538 & 5.1 & 661 & 5.7 & 960 & 3.1 \\
\hline 11 & Methionine & «r» & 877 & 2.9 & 263 & 2.3 & 770 & 2.4 \\
\hline 12 & Proline & «i & 1410 & 4.7 & 593 & 5.1 & - & - \\
\hline 13 & Serine & «i $»$ & 1888 & 6.2 & 656 & 5.6 & 1850 & 5.9 \\
\hline 14 & Tyrosine & «i $»$ & 1200 & 4.0 & 383 & 3.3 & 1670 & 5.4 \\
\hline 15 & Threonine & «r» & 1091 & 3.6 & 438 & 3.8 & 1580 & 5.1 \\
\hline 16 & Tryptophan & $\ll \mathrm{r} »$ & \multicolumn{4}{|c|}{ Not determined } & 210 & 0.7 \\
\hline 17 & Phenylalanine & $\langle\mathrm{r} »$ & 1396 & 4.6 & 525 & 4.5 & 1740 & 5.6 \\
\hline 18 & Cysteine & «i» & 604 & 2.0 & 163 & 1.4 & 1570 & 5.0 \\
\hline & Total & & 30223 & 100 & 11638 & 100 & 31220 & 100 \\
\hline
\end{tabular}

From the data Table 7, it can be seen that hemp seed of Ukrainian breeding has a high content of essential amino acids. The content of isoleucine, leucine, lysine, methionine, threonine, phenylalanine significantly exceeds their content in the hemp seed output. High lysine content is found which is usually deficient. Data on increasing the biological value of products can be significantly improved by further processing of hemp seeds to produce flour or protein. In particular, due to the use of post-processing processes, the protein content in terms of solids in hemp flour can reach $44.0 \%$, and in hemp protein $-52.1 \%$.

\section{Conclusions}

1. On the basis of a systematic approach and analysis of chemical and technological lipidcontaining systems, in particular on the oxidation and scorching of unsaturated and saturated acylglycerols in oils, seeds, and products, the purpose and methodology of studies are considered, taking into account the provisions of the systemic health concept.

2. The content of fatty acids, phospholipids, vitamins A and E, their degree of unsaturation the obtained pressed hemp oil has a high biological value. In terms of tocopherols content, hemp pressed oil significantly outweighs sunflower, sesame and amaranth oils. It is found that the ratio of essential fatty acids in hemp oil is close to perfect: Omega- 


\section{Food Technology}

6 and Omega-3 as 3.0:1 - 3.7:1, while in linseed oil - 1:3.6. Hemp oil also contains biologically valuable gamma-linolenic acid.

3. In chemical terms and less integral value (totox), hemp oil is better stored at $8 \pm 2{ }^{\circ} \mathrm{C}$ without light access.

4. Chemical indicators, in particular, peroxide and acid numbers, of hemp oil and KTIOLLK oil compositions (from mixtures of flax seeds and hemp) were found to be of good quality. KTIOL-LK11 oil composition (peroxide and acid numbers less than 1) with a higher oil output is preferred.

5. The physicochemical indicators of the hemp seeds kernel quality are improving compared to the output seeds. The oil and protein content increased 1.5 times, the macro- and trace elements (except calcium and manganese) increased: phosphorus 1.5 times, ferric -1.25 times, zinc and cobalt -2 times. Hemp seeds kernel has a high content of essential amino acids, which significantly exceeds its content in the output seed. High lysine content is found which is usually deficient.

Further research will focus on identifying new technological innovative solutions for the integrated processing of organic hemp industrial seeds, the identification, creation, and use of biologically active, functional products, supplements and preparations in the systemic health concept.

Acknowledgements. The authors are grateful to Senior Researcher D. Petrachenko for assistance in obtaining pressed oil and hemp seeds kernel; Associate Professors V. Yefimov and D. Masyuk for assistance in conducting research to determine the quality indices of industrial hemp seeds and their processing products; Lead Dr. V. Shevchyk for his assistance in testing product samples in the $\mathrm{KTIOL}^{\circledR}$ system.

\section{References}

1. Oseiko M.I. (2006), Tekhnolohiia roslynnykh olii, Varta, Kyiv.

2. O'brien R.D. (2008), Fats and oils: formulating and processing for applications, CRC Press Book, Boca Raton.

3. Oseiko M.I. (2008), Gerodietic products, dietary supplements and heroprotectors in the KTIOL system, Dairy Industry, 3, pp. 51-56.

4. Nikberg I.I. (2011), Functional foods in the structure of modern power, International Journal of Endocrinology, 6 (38), pp. 64-71.

5. Serkov V.A. (2012), Selektsiya i semenovodstvo odnodomnoy beznarkoticheskoy konopli v lesostepi srednego povolzh'ya: monografiya, RIO PGSHA, Penza.

6. Borhade S.S. (2013), Chemical Composition and Characterization of Hemp (Cannabis sativa) Seed oil and essential fatty acids by HPLC Method, Archives of Applied Science Research, 5 (1), pp. 5-8.

7. (2017), Naturally Splendid Receives Provisional Patent for Hemp Protein Isolate From U.S. Patent Office, Available at https://www.thenewswire.com/archives/AlpFYojy-naturallysplendid-receives-provisional-patent-for-hemp-protein-isolate-from-us-patentoffice.htm.

8. Oseiko N.I., Shevchyk V.I (2015), Gerontological aspects of prevention of ophthalmic diseases in the system KTIOL II, Pharmacology, Pharmaceutical Technology and 
Pharmacotherapy in Active Longevity: a book of abstracts of the II International Scientific Conference, OIHN.

9. Sova N., Lutsenko M., Lobanova A., Grekova N. (2019), Vykorystannia konoplianoi olii v tekhnolohii maionezu, Visnyk Natsionalnoho tekhnichnoho universytetu «KhPI», 5, pp. $152-159$.

10. Sova N., Lutsenko M., Yefimov V., Kurhalin S. (2018), Kharakterystyka sypkykh konoplianykh produktiv, Visnyk Natsionalnoho tekhnichnoho universytetu «KhPI», 45 (1321), pp. 207-213.

11. Oseyko M., Shevchyk V., Pokryshko O. (2019), Antimicrobial and antifungal activity of model drugs on the basis of food plant extracts in the systemic concept of health, Ukrainian Journal of Food Science, 7(1), pp. 70-82.

12. Shcherbakov V.G. (1999), Biokhimiya rastitel'nogo s'ir'ya, Kolos, Moscow.

13. Nechaev A.P. (2001), Pishchevaya khimiya, GIORD, St. Petersburg.

14. Abuzaytoun R., Shahidi F. (2006), Oxidative stability of flax and hemp oils, Journal of the American Oil Chemists`Society, 83 (10), pp. 855-861.

15. Chen T., He J., Zhang J., Li X., Zhang H., Hao J., Li L. (2012), The isolation and identification of two compounds with predominant radical scavenging activity in hempseed (seed of Cannabis sativa L.), Food Chemistry, 134 (2), pp. 1030-1037.

16. Sova N., Lutsenko M., Korchmaryova A., Andrusevych K. (2018), Research of Physical and Chemical Parameters of Oil Obtained from Organic and Conversion Hemp Seeds Varieties «Hliana», Ukrainian Food Journal, 7 (2), pp. 244-252.

17. Pavlovic R., Nenna G., Calvi L., Panseri S., Borgonovo G., Giupponi L., Cannazza G., Giorgi A. (2018), Quality Traits of «Cannabidiol Oils»: cannabinoids content, terpene fingerprint and oxidation stability of European commercially available preparations, Molecules, 23 (5), pp. 1230-1255.

18. Kabanets V., Virovets V., Laiko I. (2012), Nenarkotychni posivni konopli - kultura nevycherpnykh mozhlyvostei, Ahrobiznes sohodni, 11(234), Available at http://agrobusiness.com.ua.

19. Sova N., Voitaniyek D., Lutsenko M., Petrachenko D. (2019), Osoblyvosti pisliazbyralnoi obrobky nasinnia promyslovykh konopel, Visnyk Khersonskoho natsionalnoho tekhnichnoho universytetu, 68 (1), pp. 129-135.

20. Vonapartis E., Aubin M.P., Seguin P., Mustafa A.F., Charron J.-B. (2015), Seed composition of ten industrial hemp cultivars approved for production in Canada, Journal of Food Composition and Analysis, 39, pp. 8-12.

21. (2016), Piatirka svitovykh vyrobnykiv konoplianoho nasinnia, Asotsiatsiia «Ukrainski tekhnichni konopli», Available at: http://www.tku.org.ua/uk/news/5186.

22. Ministerstvo ahrarnoi polityky ta prodovolstva Ukrainy (2019), Derzhavnyi reiestr sortiv roslyn, prydatnykh dlia poshyrennia v Ukraini na 2019 rik stanom na 16.08.2019, Kyiv.

23. (2015), Oil production, Available at: http://dspace.knau.kharkov.ua/jspui/ bitstream/123456789/104/10.

24. Lyalina N.P. (2014), Svitovyi ta vitchyznianyi dosvid vykorystannia konopel dlia vyhotovlennia tovariv shyrokoho vzhytku, Visnyk Khersonskoho natsionalnoho tekhnichnoho universytetu, 2, pp. 86-90.

25. Zhou Y., Wang S., Lou H., Fan P. (2018), Chemical constituents of hemp (Cannabis sativa L.) seed with potential anti-neuroinflammatory activity, Phytochemistry Letters, 23, pp. 5761.

26. Shelenga T.V., Grigoriev S.V., Illarionova K.V. (2012), Biokhimicheskaya kharakteristika semyan i volokna obraztsov konopli (Cannabis sativa L.) iz kollektsii VIR im. N.I. Vavilova, Trudy po prikladnoy botanike, genetike i selektsii, 170, pp. 193-219.

27. Kiralan M., Gül V., Metin Kara S. (2010), the Fatty acid composition of hempseed oils from different locations in Turkey, Spanish Journal of Agricultural Research, 8 (2), pp. 385-390. 